\title{
Screening Common Bean (Phaseolus vulgaris) for Resistance to Tomato yellow leaf curl virus
}

\author{
Moshe Lapidot, Department of Virology, Agricultural Research Organization, the Volcani Center, Bet Dagan \\ 50250, Israel
}

\begin{abstract}
Lapidot, M. 2002. Screening common bean (Phaseolus vulgaris) for resistance to Tomato yellow leaf curl virus. Plant Dis. 86:429-432.

Commercial cultivars of common bean (Phaseolus vulgaris) were screened for resistance to Tomato yellow leaf curl virus (TYLCV). Fourteen-day-old bean plants were inoculated with TYLCV by means of the whitefly vector (Bemisia tabaci). Following inoculation, plants were sprayed with an insecticide, kept in an insect-proof greenhouse for 4 weeks, and monitored for disease symptom development. The presence of viral DNA in the inoculated plants was assayed by dot blot hybridization and by polymerase chain reaction. Out of the 42 cultivars that were tested, 24 were found to be susceptible: the plants exhibited severe symptoms and accumulated high levels of viral DNA. In all, 18 cultivars were found to be resistant to the virus: 1 cultivar showed mild symptoms while the other 17 showed no symptoms following inoculation. From the 17 symptomless cultivars, plants of 3 cultivars contained viral DNA while no viral DNA was detected in the plants of the other 14 cultivars. When the effect of bean plant age on viral inoculation by whiteflies was assayed, it was found that the success rate of TYLCV infection was highly dependent on bean plant age. When 14-day-old susceptible bean plants were inoculated, nearly $100 \%$ infection was achieved but, when 26- or 12-day-old plants of the same cultivar were inoculated, the infection rates were only 34 and 40\%, respectively.
\end{abstract}

Tomato yellow leaf curl virus (TYLCV) is, at present, the most devastating virus of cultivated tomato in tropical and subtropical regions. The virus is a monopartite begomovirus, transmitted by the tobacco whitefly (Bemisia tabaci), whose population outbursts are usually associated with high incidence of the disease $(4,13)$.

Control measures in infected regions are all based on limitation of the vector population. Chemical control has been only partially effective and, in addition to the deleterious effect of such measures on the environment, the vector has been shown to develop pesticide resistance (13). The use of fine-mesh screens has become widespread as a means of protecting crops (4). Recently, it has been shown that UVabsorbing plastic sheets and screens inhibit penetration of whiteflies into covered greenhouses $(2,3)$. However, these screens create problems of overheating and poor ventilation, and their use is relatively expensive (4). Thus, the best way to reduce TYLCV spread and to inhibit its dele-

Corresponding author: M. Lapidot

E-mail: lapidotm@netvision.net.il

Contribution from the Agricultural Research Organization, the Volcani Center, Bet Dagan, Israel. Number 526/01.

Accepted for publication 8 December 2001.

Publication no. D-2002-0222-01R

(C) 2002 The American Phytopathological Society terious effects is by breeding plants resistant or tolerant to the virus $(4,9,13)$.

It has been known for quite some time that the common bean (Phaseolus vulgaris) is susceptible to infection by TYLCV (4). However, there have been no reports in Israel of TYLCV epidemics in bean, despite the fact that bean cultivars are grown in Israel and that TYLCV and its whitefly vector are present in all agricultural areas of the country. Recently, a severe outbreak in fresh-market bean of a viral disease that has caused severe economic losses was reported in Spain (11), and the virus responsible was found to be TYLCV (11). Moreover, bean plants are used in Spain as an intercrop between tomato seasons; therefore, the bean plants served as a TYLCV reservoir and caused an increase in TYLCV epidemics in the tomato crop that was planted following the bean harvest $(11,14)$. It was concluded that the need for TYLCV-resistant cultivars has clearly increased (11). In the present article, we report the screening of commercial cultivars of bean for resistance to the virus. The plants were assayed according to symptoms and viral DNA accumulation. In order to determine the optimal plant age for inoculation and subsequently screening for TYLCV resistance, the effect of bean plant age on the success rate of TYLCV infection was examined.

\section{MATERIALS AND METHODS}

Virus. The TYLCV used in this study was from the original culture described by
Cohen and Nitzany (5). This culture, which originated from the field, is a mixture of two TYLCV isolates described by Navot et al. (12) and Antignus and Cohen (1). The virus was maintained in an insect-proof greenhouse and propagated in tomato (Lycopersicon esculentum) plants.

Plant material. The following commercial cultivars of common bean (P. vulgaris) were used for screening for TYLCV resistance: Gina, Tema, Zeus, RS 1409 (Asgrow Seeds, Oxnard, CA); Benton, Contender, Maxidor, Provider, Scala, (Bakker Brothers, Nord-Scharwoude, The Netherlands); Hialea, Wonder Bush (Harris Moran Seed Company, Modesto, CA); Bush Romano (Heirloom Seeds, West Elizabeth, PA); Celtic, Echo, Goldie, Venture, Wax 216, 4087, 4095, (Novartis Seeds Inc., Boise, ID); Paloma, Speedy (Nunhems Zaden BV, Haelen, The Netherlands); Cantara, Maestro, Scylla (POP Vriend, The Netherlands); Alubia Blanca, Aphrodite, Astro, Barbounia, Blue Crop, Bonanza, Bonvert, Burpee's Richgreen, Colana, Cyprus, DGV, Marona, Nirda, Olympia, Phoenix Claudia, Pinto Amber, Pure Gold Wax, and 148 (Israel Gene Bank, Bet Dagan, Israel).

Whitefly maintenance and plant inoculation. Whitefly colonies were reared on cotton plants grown in muslin-covered cages held in an insectary greenhouse. Whiteflies were given a 48-h acquisition access period to TYLCV-infected tomato source plants, after which they were allowed a 48-h inoculation access period on 14-day-old bean test plants with over 50 whiteflies per plant. Following inoculation, the plants were sprayed with Imidacloprid (Confidor, Bayer, Leverkusen, Germany), kept in an insect-proof greenhouse for 4 weeks, and monitored for TYLCV disease development. In each experiment, at least seven plants from each cultivar were tested. Each cultivar was tested in at least three separate experiments.

Effect of plant age on inoculation. Seed of a susceptible bean cultivar (Goldie) were sown on several dates, 10 seed each time. The plants from all the sowings were inoculated simultaneously by using over 50 whiteflies per plant, as described above. Following inoculation, the plants were sprayed with Imidacloprid and kept in an insect-proof greenhouse for 4 weeks and the percentage of plants showing symptoms was determined. The experiment was repeated with five differ- 

are averages of those of the five separate inoculations.

Viral DNA detection. Viral DNA was detected in the upper leaves of the infected bean plants either by dot blot hybridization or by polymerase chain reaction (PCR). Leaf tissue $(0.1 \mathrm{~g})$ from the plant apex was ground in $0.5 \mathrm{ml}$ of $0.4 \mathrm{M} \mathrm{NaOH}$, and 10$\mu \mathrm{l}$ aliquots were dotted on a nylon membrane (Hybond $\mathrm{N}+$, Amersham Pharmacia, Freiburg, Germany) as described previously (8). For background determination, samples were taken from noninoculated bean plants. TYLCV cDNA served as a ent independent inoculations. The results template for the production of an in vitro-

synthesized ${ }^{32} \mathrm{P}$-labeled viral riboprobe corresponding to the full-length viral genome. The membrane was reacted with the labeled viral riboprobe, washed, and exposed to a phosphorimager screen (Bioimaging analyzer, BAS-1500; FUJIFILM, Tokyo).

TYLCV DNA also was detected in the inoculated bean plants by PCR. Total nucleic acids were extracted from the apex of the infected bean plants according to Dellaporta et al. (7) and served as templates for PCR amplification. An 856-ntlength DNA fragment, corresponding to the $5^{\prime}$ half of the $\mathrm{C} 1$ gene of TYLCV, was amplified by means of the primers TYC1F

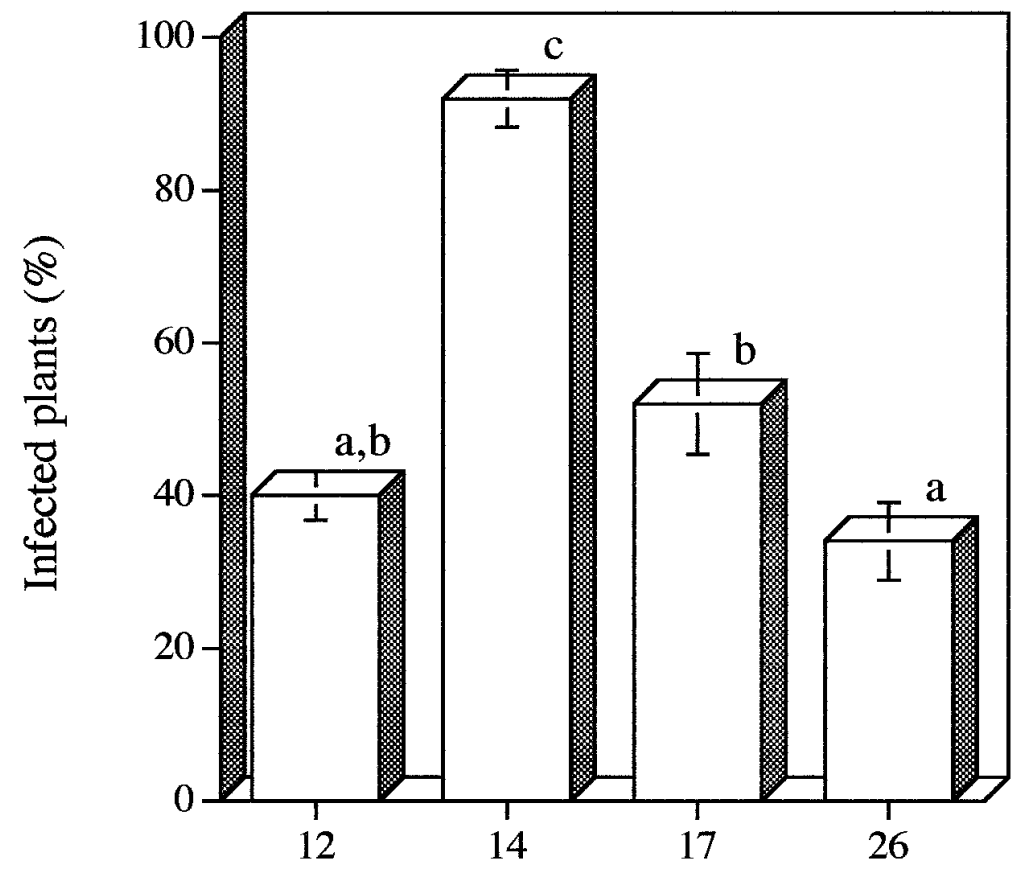

\section{Days after sowing}

Fig. 1. Effect of bean plant age on Tomato yellow leaf curl virus (TYLCV) infection following inoculation by whiteflies. Susceptible bean plants (cv. Goldie) were inoculated at different ages with TYLCV. Ten plants were used for each time point. The experiment was repeated with five different independent inoculations. The graph represents the averages of the results of five separate inoculations. Different letters denote means $( \pm$ SER $)$ that differ significantly $(P<0.05)$.
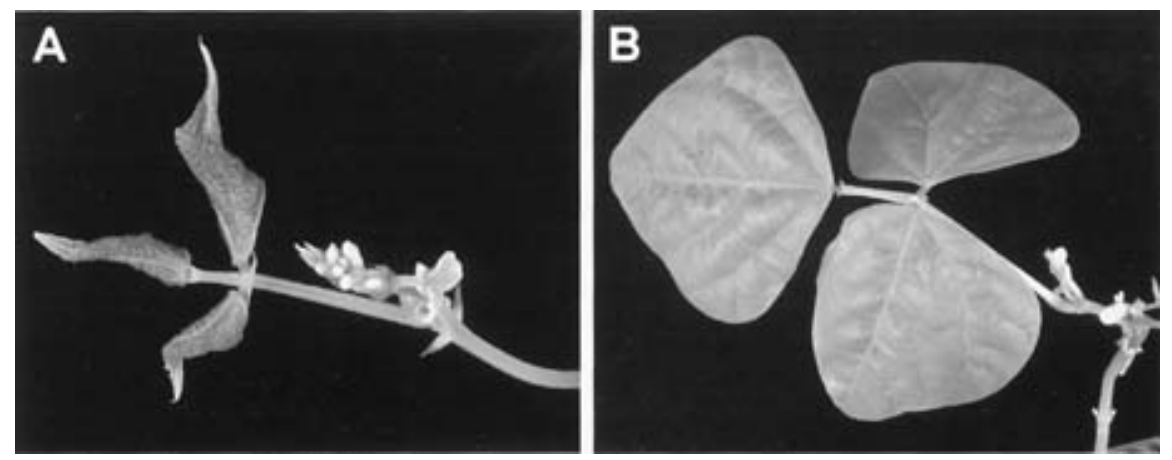

Fig. 2. Expression of Tomato yellow leaf curl virus (TYLCV) symptoms by bean plants. Fourteenday-old bean plants were inoculated with TYLCV. Photographs were taken 3 weeks after inoculation. A, Typical symptoms of a susceptible bean plant (cv. Benton). B, Symptomless resistant plant (cv. Cantara).
(5'-GGGCCTAGAGACCTGGCCCAC-3', nucleotides 2087 to 2107$)$, and TYC1R (5'CCGGTAATATTATACGGATGGC-3', nucleotides 171 to 150 ), based on the published sequence of TYLCV-IL (12).

Statistical analysis was carried out by means of one-way analysis of variance (SAS Institute, Cary, NC).

\section{RESULTS}

The effect of bean plant age on the success rate of TYLCV inoculation was assayed by inoculating a susceptible bean cultivar (Goldie) at several different ages (Fig. 1). When 14-day-old plants were inoculated, an infection rate of $92 \%$ was achieved. Susceptible plants usually developed severe disease symptoms within 2 weeks. Symptoms consisted of downward curling, crumpling, thickening, and elongation of leaves, and severe stunting (Fig. 2). When infected plants were maintained for 2 to 3 months under greenhouse conditions, little fruit production occurred (data not shown). However, the infection rate dropped markedly to $34 \%$ when younger (12-day-old) plants were inoculated, and to 50 and $40 \%$ when older plants were inoculated (17- or 26-day-old plants, respectively; Fig. 2). Moreover, disease symptoms were delayed several days in plants inoculated at 26 days of age compared with those inoculated at 14 days of age. Under greenhouse conditions described in these experiments, 12-day-old plants had developed an immature primary leaf, with the first trifoliate leaf at bud stage. Fourteen-day-old plants had fully developed primary leaves, the first trifoliate leaf had expanded, and the second trifoliate leaf was budding. The 17-day-old plants had two trifoliate leaves with budding of the third; and 26-day-old plants had three fully developed trifoliate leaves, the fourth not fully developed, and the beginning of a fifth.

Following inoculation at the 14-day-old plant stage, the bean cultivars were screened for their reactions to the virus on the basis of development of disease symptoms (Table 1). Twenty-four cultivars were found to be highly susceptible; these plants exhibited severe TYLCV disease symptoms, usually within 2 weeks following inoculation. The severity of disease symptoms exhibited by the different susceptible cultivars was similar. In all, 4 cultivars were found to be tolerant and 14 cultivars were found to be resistant to the virus; these plants exhibited no disease symptoms at all, except in plants of cv. Scylla, which exhibited very mild symptoms (Table 1 ). All the susceptible cultivars accumulated medium to high levels of viral DNA, as determined by dot blot hybridization, but this technique detected viral DNA only in the four tolerant cultivars. No viral DNA was detected in the resistant cultivars (Table 1). When the more sensitive PCR assay was used, a single band of the 
expected size of $856 \mathrm{nt}$, corresponding closely to the $5^{\prime}$ half of the $\mathrm{C} 1$ gene of TYLCV, was amplified (data not shown). A strong band was amplified when DNA was extracted from infected susceptible plants, while a weak DNA band was detected in the four tolerant cultivars (Table 1). However, no viral DNA was detected in the 14 resistant cultivars (Table 1). When whiteflies were feeding on the different bean cultivars following acquisition from TYLCV-infected source plants, no preference to any bean cultivar was observed. Whiteflies were feeding on all the different bean plants in the same manner (data not shown). Thus, all bean cultivars, susceptible and resistant alike, were uniformly inoculated.

Table 1. Reaction of different bean cultivars to inoculation with Tomato yellow leaf curl virus $(\text { TYLCV })^{\mathrm{a}}$

\begin{tabular}{|c|c|c|c|}
\hline \multirow[b]{2}{*}{ Bean cultivar } & \multirow[b]{2}{*}{ TYLCV symptoms } & \multicolumn{2}{|c|}{ TYLCV DNA detection ${ }^{b}$} \\
\hline & & Dot blot & PCR \\
\hline \multicolumn{4}{|l|}{ Susceptible } \\
\hline Astro & Severe & + & ND \\
\hline Aphrodite & Severe & + & $+\mathrm{s}$ \\
\hline Barbounia & Severe & + & $+\mathrm{s}$ \\
\hline Benton & Severe & + & ND \\
\hline Blue Crop & Severe & + & $+\mathrm{s}$ \\
\hline Bonanza & Severe & + & $+\mathrm{s}$ \\
\hline Bonvert & Severe & + & $+\mathrm{s}$ \\
\hline Burpee's Richgreen & Severe & + & ND \\
\hline Bush Romano & Severe & + & ND \\
\hline DGV & Severe & + & $+\mathrm{s}$ \\
\hline Echo & Severe & + & ND \\
\hline Gina & Severe & + & $+\mathrm{s}$ \\
\hline Goldie & Severe & + & $+\mathrm{s}$ \\
\hline Hialea & Severe & + & $+\mathrm{s}$ \\
\hline Marona & Severe & + & ND \\
\hline Maxidor & Severe & + & $+\mathrm{s}$ \\
\hline Olympia & Severe & + & ND \\
\hline Phoenix Claudia & Severe & + & ND \\
\hline Provider & Severe & + & ND \\
\hline Pure Gold Wax & Severe & + & $+\mathrm{s}$ \\
\hline Wax 216 & Severe & + & $+\mathrm{s}$ \\
\hline Zeus & Severe & + & ND \\
\hline 148 & Severe & + & ND \\
\hline RS 1409 & Severe & + & ND \\
\hline \multicolumn{4}{|l|}{ Tolerant } \\
\hline Maestro & None & + & $+\mathrm{w}$ \\
\hline Paloma & None & + & $+w$ \\
\hline Scala & None & + & $+w$ \\
\hline Scylla & Mild & + & $+w$ \\
\hline \multicolumn{4}{|l|}{ Resistant } \\
\hline Alubia Blanca & None & _- & _- \\
\hline Cantara & None & - & - \\
\hline Celtic & None & _- & _- \\
\hline Colana & None & - & - \\
\hline Contender & None & _- & _- \\
\hline Cyprus & None & - & - \\
\hline Nirda & None & - & - \\
\hline Pinto Amber & None & _- & _- \\
\hline Speedy & None & - & - \\
\hline Tema & None & _- & _- \\
\hline Venture & None & - & - \\
\hline Wonder Bush & None & _- & _- \\
\hline 4087 & None & - & - \\
\hline 4095 & None & _- & _- \\
\hline
\end{tabular}

${ }^{a}$ Fourteen-day-old bean plants of different cultivars (seven plants of each cultivar) were inoculated with TYLCV. Following inoculation, the plants were kept for 4 weeks and monitored for disease development. TYLCV DNA was detected in inoculated plants either by dot blot hybridization or by polymerase chain reaction (PCR). Leaves from five plants of each cultivar were pooled for analysis.

b Symbols: + denotes viral DNA was detected; s and w denote strong and week DNA bands, respectively; - denotes viral DNA not detected; ND denotes not done. following amplification from susceptible plants. Thus, these four cultivars were tolerant to the disease (6). No viral DNA was detected in the other 14 resistant cultivars by either detection method. No feeding preference by the whiteflies to any bean cultivar was observed. Thus, the plants of these 14 resistant cultivars seem to be immune to TYLCV (6).

Our results have clearly demonstrated that the success rate of TYLCV infection was highly dependent on bean plant age, with the highest infection rates occurring in 14-day-old plants. Infection rates decreased when the inoculated plants were either younger or older than the optimum age of 14 days. A strong effect of plant age on infection successes was found when bean plants were inoculated with a different begomovirus, Bean golden mosaic virus (BGMV; 10). Infection rates dropped from $100 \%$ infection in 7-day-old plants to $0 \%$ infection in 12-day-old plants. Thus, the same phenomenon is observed in both studies-a distinct dependence of infection success rates with bean plant age. The differences in infection rates between the two studies could be explained by the different inoculation method that was usedBGMV was inoculated mechanically rather than by viruliferous whiteflies (10).

Interestingly, although TYLCV and its whitefly vector are present in all agricultural areas of Israel, there is no record of TYLCV epidemics in bean. This is probably due to the fact that the major bean season in Israel is in early spring; thus, bean crops are planted and harvested before the buildup of large whitefly populations. Moreover, according to companies selling bean seed, the two most popular bean cultivars grown in Israel are Venture and Cantara, which were found to be resistant to TYLCV (Table 1). This may explain their popularity as well as the freedom from TYLCV epidemics in bean in Israel.

\section{ACKNOWLEDGMENTS}

I thank S. Cohen (Department of Virology, Volcani Center) for critically reviewing the manuscript; and R. Hadas (Seeds Department, Volcani Center), M. Manoch (Israel Gene Bank), and Y. Rotem (Shok Chaklai) for their assistance in obtaining bean seed.

\section{LITERATURE CITED}

1. Antignus, Y., and Cohen, S. 1994. Complete nucleotide sequence of an infectious clone of a mild isolate of tomato yellow leaf curl virus (TYLCV). Phytopathology 84:707-712.

2. Antignus, Y., Mor, N., Joseph, B., Lapidot, M., and Cohen, S. 1996. Ultravioletabsorbing plastic sheets protect crops from insect pests and from virus diseases vectored by insects. Environ. Entomol. 25:919-924.

3. Antignus, Y., Nestel, D., Cohen, S., and Lapidot, M. 2001. Ultraviolet-deficient greenhouse environment affects whitefly attraction and flight-behavior. Environ. Entomol. 30:394-399.

4. Cohen, S., and Antignus, Y. 1994. Tomato yellow leaf curl virus, a whitefly-borne geminivirus of tomatoes. Adv. Dis. Vector Res. 
10:259-288.

5. Cohen, S., and Nitzany, F. E. 1966. Transmission and host range of tomato yellow leaf curl virus. Phytopathology 56:1127-1131.

6. Cooper, J. I., and Jones, A. T. 1983. Responses of plants to viruses: proposals for the use of terms. Phytopathology 73:127-128.

7. Dellaporta, S. L., Wood, J., and Hicks, J. B. 1983. A plant DNA minipreparation version II. Plant Mol. Biol. Rep. 1:19-21.

8. Lapidot, M., Friedmann, M., Lachman, O., Yehezkel, A., Nahon, S., Cohen, S., and Pilowsky, M. 1997. Comparison of resistance level to tomato yellow leaf curl virus among commercial cultivars and breeding lines. Plant Dis. 81:1425-1428.
9. Lapidot, M., Goldray, O., Ben-Joseph, R., Cohen, S., Friedmann, M., Shlomo, A., Nahon, S., Chen, L., and Pilowsky, M. 2000. Breeding tomatoes for resistance to tomato yellow leaf curl begomovirus. EPPO Bull. 30:317-321.

10. Morales, F. J., and Niessen, A. I. 1988. Comparative responses of selected Phaseolus vulgaris germ plasm inoculated artificially and naturally with bean golden mosaic virus. Plant Dis. 72:1020-1023.

11. Navas-Castillo, J., Sanchez-Campos, S., and Diaz, J. A. 1999. Tomato yellow leaf virus-Is causes a novel disease of common bean and severe epidemics in tomato in Spain. Plant Dis. 83:29-32.
12. Navot, N., Pichersky, E., Zeidan, M., Zamir, D., and Czosnek, H. 1991. Tomato yellow leaf curl virus: a whitefly-transmitted geminivirus with a single genomic component. Virology 185:131-161.

13. Pico, B., Diez, M. J., and Nuez, F. 1996 Viral diseases causing the greatest economic losses to the tomato crop. II. The tomato yellow leaf curl virus-a review. Sci Hortic. 67:151-196.

14. Sanchez-Campos, S., Navas-Castillo, J., Camero, R., Soria, C., Diaz, J. A., and Moriones, E. 1999. Displacement of tomato yellow leaf curl virus (TYLCV)-Sr by TYLCV-Is in tomato epidemics in Spain. Phytopathology 89:1038-1043. 